\title{
High dose caffeine citrate for extubation of preterm infants: a randomised controlled trial
}

\section{P Steer, V Flenady, A Shearman, B Charles, P H Gray, D Henderson-Smart, G Bury, S Fraser, J Hegarty, Y Rogers, S Reid, L Horton, M Charlton, R Jacklin, A Walsh (The Caffeine Collaborative Study Group Steering Group)}

Arch Dis Child Fetal Neonatal Ed 2004;89:F499-F503. doi: 10.1136/adc.2002.023432
See end of article for authors' affiliations

Correspondence to: Vicki Flenady, Centre for Clinical Studies, Mater Health Services, Raymond Terrace, South Brisbane, Queensland, Australia 4101; vflenady@mater. org.au

Accepted 12 May 2004
Objective: To compare two dosing regimens for caffeine citrate in the periextubation period for neonates born at less than 30 weeks gestation in terms of successful extubation and adverse effects.

Design: A multicentre, randomised, double blind, clinical trial.

Setting: Four tertiary neonatal units within Australia.

Patients: Infants born less than 30 weeks gestation ventilated for more than 48 hours.

Interventions: Two dosing regimens of caffeine citrate $(20 \vee 5 \mathrm{mg} / \mathrm{kg} /$ day) for periextubation management. Treatment started 24 hours before a planned extubation or within six hours of an unplanned extubation.

Main outcome measure: Failure to extubate within 48 hours of caffeine loading or reintubation and ventilation or doxapram within seven days of caffeine loading.

Results: A total of 234 neonates were enrolled. A significant reduction in failure to extubate was shown for the $20 \mathrm{mg} / \mathrm{kg} /$ day dosing group (15.0\% v 29.8\%; relative risk $0.51 ; 95 \%$ confidence interval (Cl) 0.31 to 0.85 ; number needed to treat $7(95 \% \mathrm{Cl} 4$ to 24$))$. A significant difference in duration of mechanical ventilation was shown for infants of less than 28 weeks gestation receiving the high dose of caffeine (mean (SD) days 14.4 (11.1) v 22.1 (17.1); $p=0.01)$. No difference in adverse effects was detected in terms of mortality, major neonatal morbidity, death, or severe disability or general quotient at 12 months.

Conclusions: This trial shows short term benefits for a $20 \mathrm{mg} / \mathrm{kg} /$ day dosing regimen of caffeine citrate for neonates born at less than 30 weeks gestation in the periextubation period, without evidence of harm in the first year of life.
$\mathrm{R}$ espiratory distress remains a common morbidity of very preterm infants despite the widespread introduction of antenatal steroids. ${ }^{1}$ Many infants who require mechanical ventilation remain ventilator dependent for various durations from days to many weeks. For many immature infants, this is thought to be at least partly related to poor respiratory drive and a tendency to develop hypercarbia and apnoeic episodes. ${ }^{2}$ Even when a very preterm infant is successfully extubated in the short term, frequent and recurrent episodes of apnoea may lead to reintubation and the use of further mechanical ventilation. Prolonged mechanical ventilation is associated with barotrauma and the development of pulmonary morbidity including chronic lung disease. ${ }^{3}$ Accordingly various strategies have been introduced in an attempt to decrease the exposure time to mechanical ventilation, including surfactant, diuretics, and corticosteroid treatment, as well as ventilatory assistance with continuous positive airways pressure in the period after extubation. ${ }^{4}$ These interventions, however, have met with varying degrees of success.

Methylxanthines have also been used to facilitate extubation in very low birthweight infants..$^{5}$ A systematic Cochrane Review of the literature has indicated a relative risk of failed extubation of 0.48 for infants exposed to methylxanthines before extubation. ${ }^{6}$ In addition, methylxanthine treatment has been shown to be effective in the prevention and management of apnoea of prematurity. ${ }^{78}$ The two available methylxanthines, aminophylline and caffeine, have both been used in preterm infants. ${ }^{9}$ Studies comparing these two drugs have not, however, shown a difference in effectiveness, but caffeine has the advantage of a longer half life and less toxicity than theophylline. ${ }^{10}{ }^{11}$ The standard dose of caffeine citrate is a loading dose of $20 \mathrm{mg} / \mathrm{kg}$ followed by a maintenance dose of $5 \mathrm{mg} / \mathrm{kg}$ daily. ${ }^{12}$ Despite the use of caffeine citrate in these doses, up to one third of preterm infants fail extubation. Although there are limited dose-response data for caffeine, ${ }^{13}$ there is some evidence that extremely low birthweight infants may benefit from higher than the standard dosing regimen. ${ }^{14}{ }^{15}$ Henderson-Smart and Davis ${ }^{6}$ reported that methylxanthines may increase the chances of successful extubation in some preterm infants, but stated that the studies to date do not allow firm recommendations for clinical practice.

Accordingly, the aim of this trial was to determine if a higher dose of caffeine citrate $(20 \mathrm{mg} / \mathrm{kg} / \mathrm{day})$ in the periextubation period was more effective than a standard dose regimen $(5 \mathrm{mg} / \mathrm{kg} /$ day $)$ in facilitating successful extubation in very preterm infants without an increase in adverse effects.

\section{METHODS}

The multicentre trial was conducted in four Australian neonatal intensive care units (Mater Mothers' Hospital, Brisbane, Queensland; Royal Prince Alfred Hospital, Sydney, New South Wales; Mercy Hospital for Women, Melbourne, Victoria; Royal Hobart Hospital, Hobart, Tasmania). The human research and ethics committees of each collaborating centre and the University of Queensland ethics committee approved the trial. Written informed consent was obtained from at least one parent before enrolment of an eligible infant in the study. 
Infants with a gestational age at birth of less than 30 weeks who had received or who were expected to receive at least 48 hours of mechanical ventilation were eligible for entry. This periextubation group was part of a larger clinical trial assessing high and low dose caffeine in infants of less than 30 weeks gestation requiring methylxanthine for either periextubation management or treatment of apnoea. The results of the larger trial will be reported elsewhere.

In this trial, infants were excluded for one or more of the following reasons: major congenital abnormality, sepsis (confirmed by blood culture), major neurological condition, grade 3 or 4 intraventricular haemorrhage, previous methylxanthine treatment.

Infants were randomised using a computer generated list of random numbers by a hospital pharmacist who was not associated in any other way with the study or with the clinical management of infants. Randomisation was stratified by indication for caffeine treatment (periextubation and treatment), by centre, and by gestational age (less than 28 weeks gestation and 28-29 weeks gestation). Two series of $2 \mathrm{ml}$ unit dose sterile ampoules containing $20 \mathrm{mg} / \mathrm{ml}$ and $5 \mathrm{mg} / \mathrm{ml}$ caffeine citrate in water for injections BP (equivalent to $10 \mathrm{mg} / \mathrm{ml}$ and $2.5 \mathrm{mg} / \mathrm{ml}$ caffeine base) were prepared by a contract pharmaceutical manufacturer (Opthalmic Laboratories, Sydney, Australia). The two strengths of caffeine citrate were identical in appearance. Investigators and clinical staff were blind to treatment allocation.

Infants enrolled into the periextubation group were randomly allocated to one of the two dose groups either 24 hours before a planned extubation, or within six hours of an unexpected extubation. A loading dose of $4 \mathrm{ml} / \mathrm{kg}$ - that is, either $80 \mathrm{mg} / \mathrm{kg}$ or $20 \mathrm{mg} / \mathrm{kg}$ - caffeine citrate was administered over 15 minutes by intravenous injection. ${ }^{16}$ A maintenance dose of $1 \mathrm{ml} / \mathrm{kg}$ (either $20 \mathrm{mg} / \mathrm{kg}$ or $5 \mathrm{mg} / \mathrm{kg}$ ) was given in an identical manner at 24 hourly intervals starting 24 hours after the loading dose for the duration of caffeine treatment. Infants received the maintenance dose either intravenously or, if on full enteral feeds, through the orogastric tube. Owing to supply difficulties, 34 infants received caffeine for the first seven days of methylxanthine treatment only, and then continued on theophylline. Postextubation management included extubation to nasopharyngeal continuous positive airways pressure for at least 24 hours. Heart rate, respiratory monitoring, and oxygen saturation monitoring was conducted as per routine nursery practice. Standardised apnoea recording sheets were distributed to all collaborating centres.

Bradycardia was defined as an episode in which the heart rate fell to less than 100 beats/min, desaturation as an

\begin{tabular}{|c|c|c|}
\hline & $\begin{array}{l}20 \mathrm{mg} / \mathrm{kg} \\
(\mathrm{n}=113)\end{array}$ & $\begin{array}{l}5 \mathrm{mg} / \mathrm{kg} \\
(\mathrm{n}=121)\end{array}$ \\
\hline Gestational age (weeks)* & $27.1(1.4)$ & $27.4(1.4)$ \\
\hline Less than 28 weeks gestation $\dagger$ & $63(56)$ & $57(47)$ \\
\hline Birth weight (g)* & $1009.2(255.6)$ & $1010.5(239.6)$ \\
\hline Age at enrolment (days) $\ddagger$ & $4.0(1.9-12.0)$ & $3.9(2.0-11.0)$ \\
\hline $\begin{array}{l}\text { Mechanical ventilation at } \\
\text { enrolment (days) } \ddagger\end{array}$ & $4.7(2.5-12.7)$ & $4.2(2.29-12.41)$ \\
\hline Nil antenatal steroids $\uparrow$ & $16(14)$ & $15(12)$ \\
\hline Respiratory distress syndrome $\dagger$ & $96(85)$ & $110(91)$ \\
\hline Exogenous surfactant† & $90(80)$ & $101(84)$ \\
\hline Male sex $\dagger$ & $55(49)$ & $63(52)$ \\
\hline White† & $99(88)$ & $108(89)$ \\
\hline Multiple pregnancy $\dagger$ & $36(32)$ & $43(36)$ \\
\hline
\end{tabular}

episode with a fall in oxygen saturation to less than $85 \%$, and apnoea a breathing pause of 20 seconds, or greater. Clinical staff were instructed to follow routine practice for any single abnormal cardiorespiratory event: initial intervention by stimulation alone, followed by oxygen administration, bag and mask ventilation, and finally intubation and mechanical ventilation. In cases of recurrent episodes of abnormal cardiorespiratory events not responding to the allocated caffeine dosage regimen, the caffeine study medication was continued with further interventions such as nasopharyngeal continuous positive airways pressure, doxapram infusion, or mechanical ventilation as deemed necessary. The decisions on the timing of extubation, the reinstitution of mechanical ventilation, the duration of nasopharyngeal continuous positive airways pressure (more than 24 hours after extubation), the use of doxapram, and the duration of caffeine treatment was left to the attending clinician. Infants requiring continued methylxanthine treatment, but transferred from the tertiary to regional centres, were changed to theophylline.

The primary outcome measure was failure of extubation from mechanical ventilation, defined as either an inability to extubate from mechanical ventilation within 48 hours of caffeine loading for a planned extubation (decision by the attending neonatologist not to attempt extubation based on the clinical condition of the infant) or the use of reintubation or doxapram within seven days of caffeine loading. Secondary outcomes included frequency of apnoeic episodes, tachycardia and jitteriness, feeding intolerance, incidence of necrotising enterocolitis, intraventricular haemorrhage, retinopathy of prematurity, and chronic lung disease of prematurity.

Infants enrolled in the trial were reviewed at 12 months corrected age for a general physical examination and neurological assessment. Psychometric testing at 12 months was by the revised Griffiths mental developmental scales. ${ }^{17}$

\section{Statistical analysis}

The a priori sample size estimate was based on the ability to detect a $50 \%$ reduction in failure of extubation from $32 \%$ to $16 \%$. An hypothesised failure rate of $32 \%$ for the low dose group is consistent with the findings from previous trials for assessing the value of methylxanthines in the periextubation period..$^{18}$ A total of 222 infants (111 infants in each group) was required using a $\alpha$ level of 0.05 with a statistical power of $80 \%$. Statistical analysis was performed using the software package Statistica (StatSoft Inc, Tulsa, Oklahoma, USA). Student's $t$ tests or Mann-Whitney U tests were performed as appropriate for continuous variables, and $\chi^{2}$ or Fishers exact test for categorical data. Subgroup analyses were planned for the stratified gestational age groups. Results were analysed on an intention to treat basis.

\section{RESULTS}

During a 31 month period (September 1996 to April 1999), 295 infants were deemed eligible for inclusion, and a total of $238(81 \%)$ were enrolled into the trial. The main reasons for not enrolling eligible infants were parental refusal (54\%), failure to approach for consent (29\%), and caffeine supply problem (13\%). Of the total of 238 infants who were randomised, 116 and 122 infants were randomised to the $20 \mathrm{mg} /$ $\mathrm{kg} /$ day and $5 \mathrm{mg} / \mathrm{kg} /$ day dose groups respectively. Four infants were excluded after randomisation, but before analysis (three in the $20 \mathrm{mg} / \mathrm{kg}$ group, one in the $5 \mathrm{mg} / \mathrm{kg}$ group) because they did not meet the inclusion criteria. Two infants had previously received methylxanthine treatment, one had major congenital anomalies, and one was 31 weeks gestation. Infants in the two groups were similar in gestational age, birth weight, postnatal age at study entry, 
Table 2 Analysis of trial data

\begin{tabular}{|c|c|c|c|c|}
\hline & $\begin{array}{l}20 \mathrm{mg} / \mathrm{kg} \\
(\mathrm{n}=113)\end{array}$ & $\begin{array}{l}5 \mathrm{mg} / \mathrm{kg} \\
(\mathrm{n}=121)\end{array}$ & $\operatorname{RR}(95 \% \mathrm{Cl})$ & p Value \\
\hline Extubation failure & $17(15 \%)$ & $36(29.8 \%)$ & $0.51(0.31$ to 0.85$)$ & $<0.01$ \\
\hline Not extubated & & & & \\
\hline Reventilated & 10 & 29 & & \\
\hline Doxapram & 1 & 0 & & \\
\hline $\begin{array}{l}\text { Duration of mechanical } \\
\text { ventilation (days) }\end{array}$ & $7.4(3.3-16.5)$ & $9.0(0.5-77)$ & & 0.38 \\
\hline Duration of NCPAP (days) & $10.1(2.3-21.2)$ & $9.8(4.3-20.1)$ & & 0.56 \\
\hline Documented apnoea & $4(1-12)$ & $7(2-22)$ & & $<0.01$ \\
\hline Documented apnoea (days)* & $0.6(0.1-2.1)$ & $1.3(0.3-4.3)$ & & 0.02 \\
\hline \multicolumn{5}{|c|}{$\begin{array}{l}\text { Values are median (interquartile range) unless otherwise indicated. Extubation failure defined as: not extubated } \\
\text { within } 48 \text { hours of caffeine, reintubation, or doxapram within seven days of caffeine loading. Documented apnoea } \\
\text { is episodes of apnoea recorded by nursing staff within seven days of the start of caffeine treatment. } \\
\text { *Non-ventilated days in successfully extubated infants ( } 85 \text { infants in the } 5 \mathrm{mg} / \mathrm{kg} \text { group and } 96 \text { in the } 20 \mathrm{mg} / \mathrm{kg} \\
\text { group). } \\
\text { NCPAP, Nasopharyngeal continuous positive airways pressure. }\end{array}$} \\
\hline
\end{tabular}

exposure to antenatal steroids, and exogenous surfactant (table 1). The starting time of the caffeine was similar in the two groups (median, $4.0 \vee 3.9$ days) as was the duration of the treatment (mean, $32.7 \vee 32.8$ days).

Analysis of the trial data (table 2) showed a significant reduction in failure to extubate in those infants receiving $20 \mathrm{mg} / \mathrm{kg} /$ day compared with $5 \mathrm{mg} / \mathrm{kg} /$ day caffeine citrate ( $15 \%$ v 29.8\%; relative risk (RR) 0.51 ; $95 \%$ confidence interval (CI) 0.31 to 0.85$)$. This difference was even greater in infants of less than 28 weeks gestation (17\% v 49\%; RR 0.36; 95\% CI 0.20 to 0.65 ). The risk difference (RD) for the whole cohort is $15 \%$, giving a number needed to treat (NNT) of 7 (95\% CI 4 to 24 ), and for the subgroup less than 28 weeks gestation an RD of $32 \%$ and NNT of 3 (95\% CI 2 to 6). Although there was no significant difference in the duration of ventilation for the whole cohort, a significant reduction was shown for the subgroup of infants less than 28 weeks gestation receiving the higher dose of caffeine (mean (SD) days 14.4 (11.1) $v$ 22.1 (17.1); $\mathrm{p}<0.01$ ). There was also a significant decrease in the number of episodes of apnoea within seven days of the start of treatment in the high dose caffeine group (median (range) $4(0-92) \vee 7(0-56))$. This decrease in apnoea was also evident in the subgroup of children who were successfully extubated (table 2).

No differences in adverse effects were detected. The number of infants experiencing tachycardia (defined as a heart rate $>200$ beats/min for four consecutive hourly interval recording) and jitteriness was similar in the groups.

\begin{tabular}{|c|c|c|c|}
\hline & $\begin{array}{l}20 \mathrm{mg} / \mathrm{kg} \\
(\mathrm{n}=113)\end{array}$ & $\begin{array}{l}5 \mathrm{mg} / \mathrm{kg} \\
(\mathrm{n}=121)\end{array}$ & $\mathrm{p}$ Value \\
\hline Tachycardia & 4 & 1 & \\
\hline Caffeine withheld & 3 & 0 & \\
\hline Jitteriness & 2 & 2 & \\
\hline Caffeine withheld & 0 & 0 & \\
\hline $\begin{array}{l}\text { Total in whom caffeine was } \\
\text { withheld* }\end{array}$ & $9(8)$ & $5(4)$ & 0.24 \\
\hline Feed intolerance* & $40(35)$ & $37(31)$ & 0.44 \\
\hline $\begin{array}{l}\text { Total parenteral nutrition } \\
\text { (days) } \dagger\end{array}$ & $14.3(8.26)$ & $15.5(10.8)$ & 0.80 \\
\hline Weight gain $(\mathrm{g} / \mathrm{kg} /$ day $) \neq$ & $\begin{array}{l}12.2(6.5- \\
15.2)\end{array}$ & $\begin{array}{l}12.6(9.2- \\
15.2)\end{array}$ & 0.35 \\
\hline $\begin{array}{l}\text { Time to regain birthweight } \\
\text { (days)t }\end{array}$ & $14.8(5.3)$ & $12.9(5.0)$ & $<0.01$ \\
\hline \multicolumn{4}{|c|}{$\begin{array}{l}\text { *Values are number (\%). } \\
\text { +Values are mean (SD). } \\
\text { fValues are median (interquartile range). } \\
\text { - Data available for } 116 \text { infants in the } 5 \mathrm{mg} / \mathrm{kg} \text { group, and } 110 \text { infants in } \\
\text { the } 20 \mathrm{mg} / \mathrm{kg} \text { group. }\end{array}$} \\
\hline
\end{tabular}

Caffeine doses were withheld in 14 babies, nine in the $20 \mathrm{mg} /$ $\mathrm{kg} /$ day dosing group and five in the $5 \mathrm{mg} / \mathrm{kg}$ /day group. There was no significant difference in the incidence of feed intolerance or the need for or duration of intravenous parenteral nutrition. Although the time to regain birth weight was significantly longer for infants in the higher dose group (mean (SD) days 14.8 (5.3) $v 12.9$ (5.0); p < 0.01), there was no difference in overall weight gain between the groups for the duration of caffeine treatment as measured by weight on cessation (table 3 ).

No significant differences were reported between the groups in outcomes of death before hospital discharge or major morbidity, necrotising enterocolitis, culture proven sepsis, pulmonary air leak, or chronic lung disease (table 4).

The results of the neurological assessment at 12 months corrected for prematurity showed a non-significant trend for benefit for infants in the high dose caffeine group compared with the low dose group in terms of death or major disability ( $13 \%$ v $21 \%$; RR 0.62 (95\% CI 0.33 to 1.14$)$ ), and an increase in the mean general quotient (mean (SD), 96.6 (13.2) $v 92.2$ (17.3)) (table 5).

\section{DISCUSSION}

Despite the extensive use of methylxanthines in neonatal care, there has been little evidence from dose-response trials to permit an evidenced based approach to dosing regimens. This pragmatic clinical trial was designed to evaluate the short term effects of two different doses of caffeine as periextubation management in newborn infants born at less than 30 weeks gestation.

An intention to treat analysis for the primary outcome measure showed a significant decrease in the incidence of failure to extubate in the high dose caffeine citrate group $(20 \mathrm{mg} / \mathrm{kg} /$ day $)$. Infants in the high dose caffeine citrate group were significantly less likely to fail extubation, or require reintubation or doxapram treatment in the subsequent seven days with a number needed to treat of only seven. This effect was more convincing in the stratified subgroup of those of less than 28 weeks gestation, where only three infants would require treatment to avoid one additional infant failing extubation. Although there was no overall difference in the duration of ventilation between the study groups, there was a significant reduction of a mean of eight days in the subgroup of infants less than 28 weeks gestation. This clinically important difference has major resource implications for neonatal intensive care. These benefits were achieved with no evidence of an increase in adverse effects.

The secondary outcome measure of apnoea was also significantly decreased in the high dose group compared 
Table 4 Major morbidity and death

\begin{tabular}{|c|c|c|c|c|}
\hline & $\begin{array}{l}20 \mathrm{mg} / \mathrm{kg} \\
(\mathrm{n}=113)\end{array}$ & $\begin{array}{l}5 \mathrm{mg} / \mathrm{kg} \\
(\mathrm{n}=121)\end{array}$ & $\operatorname{RR}(95 \% \mathrm{Cl})$ & p Value \\
\hline Proven infection & $52(46)$ & $60(50)$ & $0.93(0.71$ to 1.21$)$ & 0.59 \\
\hline Necrotising enterocolitis & 0 & $5(4)$ & & \\
\hline \multicolumn{5}{|l|}{ Intraventricular haemorrhage } \\
\hline Data available & $n=112$ & $n=121$ & & \\
\hline Total & $33(30)$ & $34(28)$ & $1.04(0.68,1.58)$ & 0.86 \\
\hline Grades 3 or 4 & 5 & 1 & & 0.11 \\
\hline \multicolumn{5}{|l|}{ at 6 weeks of age* } \\
\hline Data available & $n=97$ & $\mathrm{n}=89$ & & \\
\hline Retinopathy of prematurity & $21(23)$ & $34(33)$ & $0.68(0.43$ to 1.09$)$ & 0.11 \\
\hline Stage 3 and 4 & 3 & 8 & $0.42(0.11$ to 1.52$)$ & 0.22 \\
\hline Data available & $n=92$ & $n=102$ & & \\
\hline Pulmonary air leak & $5(4)$ & $7(6)$ & $0.77(0.25$ to 2.34$)$ & 0.64 \\
\hline \multicolumn{5}{|l|}{ Chronic lung disease } \\
\hline Chronic lung disease, 28 days $\dagger$ & $64(66)$ & $80(74)$ & $0.89(0.74$ to 1.07$)$ & 0.22 \\
\hline Data availab̆le & $n=97$ & $n=108$ & & \\
\hline Chronic lung disease, 36 weeks $\ddagger$ & $33(34)$ & $51(48)$ & $0.72(0.51$ to 1.01$)$ & 0.06 \\
\hline Data available & $n=96$ & $n=107$ & & \\
\hline Death before hospital discharge & $5(4)$ & $7(6)$ & $0.77(0.25$ to 2.34$)$ & 0.64 \\
\hline \multicolumn{5}{|c|}{$\begin{array}{l}\text { Values are number (\%). } \\
\text { *Major cerebral abnormality at } 6 \text { weeks defined as one or more of the following: cerebral cystic formation } \\
\text { (porencephalic cysts or periventricular leucomalacia or encephaloclastic porencephaly) or hydrocephalus. } \\
\text { †Oxygen requirement at } 28 \text { days of postmenstrual age in survivors at hospital discharge. } \begin{array}{l}\text { Oxygen requirement at } \\
36 \text { weeks of postmenstrual age in survivors at hospital discharge. }\end{array}\end{array}$} \\
\hline
\end{tabular}

with the low dose group. Apnoea, as measured in this trial, was by nursing record. Nurse recordings of apnoea have been shown to be inaccurate in previous studies. ${ }^{19}$ In this blinded trial, any bias should be avoided, and the nurse record, regardless of accuracy against formal computer analysis, is the critical information used by clinicians in clinical decision management-for example, need for a change of treatment.

Aranda $e t \mathrm{al}^{13}$ suggested that a clinically effective plasma caffeine concentration was 5-50 mg/l, but found no advantage in caffeine concentrations above $20 \mathrm{mg} / \mathrm{l}$ in terms of optimising ventilatory drive and apnoea control. In a previous study, we showed a significant decrease in the incidence of apnoea with the higher concentrations of caffeine (daily maintenance doses of 15 and $30 \mathrm{mg} / \mathrm{kg}$ caffeine citrate). ${ }^{15}$ Aranda $e t$ al $^{13}$ found minimal side effects with serum concentrations up to $80 \mathrm{mg} / \mathrm{l}$, with side effects limited to transient jitteriness. Recent reports have highlighted and confirmed the increase in metabolic rate and increase in oxygen consumption that accompanies caffeine treatment. ${ }^{20}$ This physiological consequence of caffeine did not result in an observed dose-response effect within this study. Although we found that the high dose caffeine group took longer to regain birth weight, there was no difference in overall weight gain between the two study groups during caffeine treatment.

Unfortunately, there are limited data on the long term effects of caffeine treatment in preterm infants. Schmidt ${ }^{21}$ highlighted the possibility of neurodevelopmental effects of caffeine exposure in preterm infants. Methylxanthines are adenosine receptor antagonists. As adenosine is protective against ischaemia, animal models suggest that the presence of methylxanthines potentially exacerbates ischaemic cerebral injury or may increase the susceptibility of the preterm brain to ischaemic injury. Unfortunately, no randomised clinical trials with long term follow up assessing caffeine treatment have been reported. One recent cohort follow up study $^{22}$ provided conflicting evidence as to the potential effects of caffeine exposure. Davis et al ${ }^{22}$ described an increase in cerebral palsy in those infants exposed to theophylline in the neonatal period, but also noted an increase in the mean intelligence quotient (IQ) in the same group of infants compared with controls not exposed to caffeine.

The long term neurodevelopmental outcome of infants was not the primary outcome of this trial; however, the results show a trend to benefit for the high dose caffeine group. Although encouraging, this result should be treated with caution because of loss to follow up of $18 \%$. There was also no difference between the high and low dose groups in terms of short term or surrogate outcome measures of neurological wellbeing-for example, severe intraventricular haemorrhage, periventricular leucomalacia, or severe retinopathy of prematurity, or a composite measure of these outcomes. Unfortunately, although reassuring in the short term, the indomethacin prophylaxis trial (TIPP) ${ }^{23}$ has given us reason to be cautious in the use of these surrogate outcome measures. Despite showing a significant difference in the incidence of severe intraventricular haemorrhage within the intervention (indomethacin) treated group of infants within

Table 5 Outcomes at 12 months corrected for prematurity

\begin{tabular}{|c|c|c|c|c|}
\hline & $\begin{array}{l}20 \mathrm{mg} / \mathrm{kg} \\
(\mathrm{n}=87)\end{array}$ & $\begin{array}{l}5 \mathrm{mg} / \mathrm{kg} \\
(\mathrm{n}=86)\end{array}$ & $\operatorname{RR}(95 \% \mathrm{CI})$ & p Value \\
\hline Developmental assessment & $\mathrm{n}=80$ & $\mathrm{n}=78$ & & \\
\hline General quotient (GQ)* & $96.6(13.2)$ & $92.2(17.3) \dagger$ & & 0.08 \\
\hline Major disability & 6 & 14 & $0.42(0.17$ to 1.05$)$ & 0.05 \\
\hline Death up to 12 months of age & 7 & 8 & & \\
\hline Death or disability & 13 & 22 & $0.58(0.32$ to 1.08$)$ & 0.08 \\
\hline
\end{tabular}


the TIPP trial, this observation did not lead to a difference in the more important long term measures of neurodevelopmental outcome. Long term studies, such as the current international multicentre trial of caffeine for apnoea of prematurity, ${ }^{21}$ are awaited with interest.

In summary, this study assessed the short term effects of caffeine treatment, and showed that a daily dose of $20 \mathrm{mg} / \mathrm{kg}$ caffeine citrate started in the periextubation period is more effective than $5 \mathrm{mg} / \mathrm{kg}$ at facilitating extubation, decreasing the duration of mechanical ventilation, and reducing apnoea after extubation. There was no increase in short term adverse effects. Although the long term outcome of caffeine treatment in preterm infants was not the primary outcome measure of this trial, a reassuring trend to benefit in the 12 month developmental outcome was noted for infants in the high dose caffeine group.

\section{ACKNOWLEDGEMENTS}

This trial was supported by the National Health and Medical Research Council, Canberra, Australia and the Mater Health Services' Private Practice Trust Fund, Brisbane, Queensland, Australia. We acknowledge the clinical staff at the participating centres for their support in the conduct of this trial. We also acknowledge Richard Hockey for assistance with data analysis and Katie Welsh for assistance with preparation of the manuscript.

\section{Authors' affiliations}

P Steer, V Flenady, A Shearman, P H Gray, J Hegarty, Y Rogers, Department of Neonatology and Centre for Clinical Studies, University of Queensland, Mater Health Services, South Brisbane, Queensland, Australia

B Charles, Australian Centre for Paediatric Pharmacokinetics, School of Pharmacy, University of Queensland

D Henderson-Smart, S Reid, Neonatal Medicine, Royal Prince Alfred Hospital and Centre for Perinatal Health Services Research, University of Sydney, New South Wales, Australia

G Bury, L Horton, M Charlton, Royal Hobart Hospital, Hobart, Tasmania. Australia

S Fraser, R Jacklin, A Walsh, Mercy Hospital for Women, Melbourne, Victoria, Australia

\section{REFERENCES}

1 Crowley P, Chalmers I, Keirse MNNC. The effects of corticosteroid administration before preterm delivery: an overview of the evidence from controlled trials. Br J Obstet Gynaecol 1990;97:1 1-25.

2 Henderson-Smart D. Pulmonary diseases in the newborn. In: Textbook of neonatology. Melbourne: Churchill Livingstone, 1986.
3 Martin RJ, Walsh-Sukys MC. Bronchopulmonary dysplasia: no simple solution. N Engl J Med 1999;340:1036-8.

4 Davis PG, Henderson-Smart DJ. Nasal continuous positive airways pressure immediately after extubation for preventing morbidity in preterm infants (Cochrane Review). Cochrane Library. Issue 2. Oxford: Update Software, 2003.

5 Aranda JV, Turmen T. Methylxanthines in apnea of prematurity. Clin Perinatol 1979:6:87-108.

6 Henderson-Smart DJ, Davis PG. Prophylactic methylxanthine for extubation in preterm infants (Cochrane Review). Cochrane Library. Issue 2. Oxford: Update Software, 2003.

7 Henderson-Smart DJ, Steer PA. Prophylactic methylxanthine for preventing of apnea in preterm infants (Cochrane Review). Cochrane Library. Issue 2. Oxford: Update Software, 2003.

8 Henderson-Smart DJ, Steer P. Methylxanthine treatment for apnea in preterm infants (Cochrane Review). Cochrane Library. Issue 2. Oxford: Update Software, 2003.

9 Steer PA, Henderson-Smart DJ. Caffeine versus theophylline for apnea in preterm infants (Cochrane Review). Cochrane Library. Issue 2. Oxford: Update Software, 2003

10 Laubscher B, Greenough A, Dimitriou G. Comparative effects of theophylline and caffeine on respiratory function of prematurely born infants. Early Hum Dev 1998;50:185-92

11 Larsen PB, Brendstrup L, Skov L, et al. Aminophylline versus caffeine citrate for apnea and bradycardia prophylaxis in premature neonates. Acta Paediatr 1995;84:360-4.

12 Comer AM, Perry CM, Figgitt DP. Caffeine citrate: a review of its use in apnoea of prematurity. Paediatr Drugs 2001;3:61-79.

13 Aranda JV Cook CE, Gorman W, et al. Pharmacokinetic profile of c affeine in the premature newborn infant with apnea. J Pediatr 1979;94:663-8.

14 Scanlon JE, Chin KC, Morgan ME, et al. Caffeine or theophylline for neonatal apnoea? Arch Dis Child 1992;67:425-8.

15 Steer $\mathbf{P}$, Flenady $\mathrm{V}$, Shearman $\mathrm{A}$, et al. Periextubation caffeine in preterm neonates: a randomised does response trial. J Paediatr Child Health 2003;39:511-15

16 Lee TC, Charles B, Steer $P$, et al. Population pharmacokinetics of intravenous caffeine in neonates with apnea of prematurity. Clin Pharmacol Ther 1997;61:628-40

17 Griffiths R. The Griffiths Mental Developmental Scales. 1996 Revision ed. Henley on Thames: Association for Research in Infant and Child Development, 1996.

18 Sims ME, Rangasamy R, Lee S, et al. Comparative evaluation of caffeine and theophylline for weaning premature infants from the ventilator. Am J Perinatol 1989:6:72-5

19 Muttitt SC, Finer NN, Tierney AJ, et al. Neonatal apnea: diagnosis by nurse versus computer. Pediatrics 1988;82:713-20.

20 Baver J, Maier K, Linderkamp O, et al. Effect of caffeine on oxygen consumption and metabolic rate in very low birth weight infants with idiopathic apnea. Pediatrics 2001;107:660-3.

21 Schmidt B. Methylxanthine therapy in premature infants: sound practice, disaster, or fruitless byway? J Pediatr 1999;135:526-8.

22 Davis PG, Doyle LW, Rickards AL, et al. Methylxanthines and sensorineural outcome at 14 years in children less than $1501 \mathrm{~g}$ birthweight. J Paediatr Child Health 2000;36:47-50

23 Schmidt B, Davis P, Moddemann D, et al. Long-term effects of indomethacin prophylaxis in extremely-low-birth-weight infants. N Engl J Med $2001 \cdot 344: 1966-72$ 